\title{
U.S. Governors and the Medicaid Expansion - No Quick Resolution in Sight
}

\section{Citation}

Sommers, Benjamin D., and Arnold M. Epstein. 2013. “U.S. Governors and the Medicaid Expansion - No Quick Resolution in Sight." N Engl J Med 368 (6) (February 7): 496-499. doi:10.1056/nejmp1215785.

\section{Published Version}

doi:10.1056/NEJMp1215785

\section{Permanent link}

http://nrs.harvard.edu/urn-3:HUL.InstRepos:14008383

\section{Terms of Use}

This article was downloaded from Harvard University's DASH repository, and is made available under the terms and conditions applicable to Other Posted Material, as set forth at http:// nrs.harvard.edu/urn-3:HUL.InstRepos:dash.current.terms-of-use\#LAA

\section{Share Your Story}

The Harvard community has made this article openly available.

Please share how this access benefits you. Submit a story.

\section{Accessibility}


for aging. Highlighting the field's orphan status, a decade-long initiative by the Substance Abuse and Mental Health Services Administration implementing evidencebased geriatric mental health and substance-abuse programs throughout the country was recently eliminated, just as the wave of Baby Boomers turning 65 began to crest. $^{1}$ On the research front, National Institutes of Health policy has inexplicably allowed the systematic exclusion of study participants over 65 years of age in federally funded research involving adults (but requires detailed justification for research that excludes women, minority groups, and children). This policy forces clinicians to extrapolate from findings on the safety and effectiveness of treatments that have been tested only in younger adults, and it perpetuates what has been called the "evidence-free" practice of geriatrics.

We believe that steps should be taken to mandate the inclusion of older adults in federally funded research unless there is scientific justification for excluding them, and we agree with the IOM that immediate steps are needed to re- store the national program supporting the implementation of geriatric community mental health and substance-use programs. Emerging Medicare accountable care organizations should integrate geriatric mental health and substance-use expertise as components of health coaching and chronic disease management for patients with complex, high-cost health conditions. The potential for prevention must also be tapped, in part through the adoption of evidence-based psychological interventions that reduce the incidence of depression among patients with health conditions associated with greater risk, such as stroke and macular degeneration. Finally, the fragmentation and neglect of services and research may be addressed by creating a dedicated federal office responsible for overseeing funding and coordination across the different agencies responsible for aging, mental health, and substance-use disorders.

Although these reforms are necessary first steps, they will be insufficient without dramatic changes in what we do and how we do it. If we recognize that mental health care is a core component of general health care for aging Americans and transform the health care workforce accordingly, there may be hope that we can weather the approaching "silver tsunami."

Disclosure forms provided by the authors are available with the full text of this article at NEJM.org.

From the Departments of Psychiatry and of Community and Family Medicine, Geisel School of Medicine at Dartmouth, Hanover, NH (S.J.B.); and the Dartmouth Institute for Health Policy and Clinical Practice, Lebanon, NH (S.J.B., J.A.N.).

This article was published on January 23 , 2013, and updated on February 7, 2013, at NEJM.org.

1. Institute of Medicine. The mental health and substance use workforce for older adults: in whose hands? Washington, DC: National Academies Press, 2012.

2. Bartels SJ, Clark RE, Peacock WJ, Dums AR, Pratt SI. Medicare and Medicaid costs for schizophrenia patients by age cohort compared with costs for depression, dementia, and medically ill patients. Am J Geriatr Psychiatry 2003;11:648-57.

3. Diachun LL, Charise A, Lingard L. Old news: why the 90 -year crisis in medical elder care? J Am Geriatr Soc 2012;60:1357-60.

4. Reynolds CF III, Albert SM. Management of mental disorders: lessons from India. Lancet 2010;376:2045-6.

5. Patel V, Araya R, Chatterjee S, et al. Treatment and prevention of mental disorders in low-income and middle-income countries. Lancet 2007;370:991-1005.

DOI: 10.1056/NEJMp1211456

Copyright @ 2013 Massachusetts Medical Society.

\section{U.S. Governors and the Medicaid Expansion - No Quick Resolution in Sight}

Benjamin D. Sommers, M.D., Ph.D., and Arnold M. Epstein, M.D.

With President Barack
Obama's reelection in No-
vember, the Affordable Care Act
(ACA) will remain the law of the
land for the foreseeable future.
But since the Supreme Court rul-
ing on the ACA, states have been
grappling with the option the
Court presented - whether to
participate in the expansion of
Medicaid eligibility to all adults with family incomes at or below $138 \%$ of the federal poverty level. In the aftermath of the 2012 election, it is uncertain how this process will play out, but what the states decide will play a critical role in the future of the U.S. health care system.

We undertook an in-depth ex- ploration of the views expressed by governors about the ACA Medicaid expansion from the time of the Supreme Court ruling in June through 1 month after the November election. Although governors are, of course, only part of the state-level policymaking process, they directly oversee each state's Medicaid program 
Table 1. Likelihood of U.S. Governors' Support for Expanding Medicaid under the ACA.*

\begin{tabular}{|c|c|c|c|c|c|}
\hline \multirow[t]{2}{*}{$\begin{array}{l}\text { State } \\
\text { (Governor's Party) }\end{array}$} & \multicolumn{2}{|c|}{$\begin{array}{c}\text { View on } \\
\text { Medicaid Expansion }\end{array}$} & \multirow[t]{2}{*}{$\begin{array}{l}\text { State } \\
\text { (Governor's Party) }\end{array}$} & \multicolumn{2}{|c|}{$\begin{array}{c}\text { View on } \\
\text { Medicaid Expansion }\end{array}$} \\
\hline & $\begin{array}{l}\text { Before } \\
\text { Election }\end{array}$ & $\begin{array}{c}\text { After } \\
\text { Election'i- }\end{array}$ & & $\begin{array}{l}\text { Before } \\
\text { Election }\end{array}$ & $\begin{array}{c}\text { After } \\
\text { Election'i }\end{array}$ \\
\hline Florida (R) & Oppose & Undecided & Alabama (R) & Undecided & Oppose \\
\hline Georgia (R) & Oppose & Oppose & Alaska (R) & Undecided & Undecided \\
\hline lowa (R) & Oppose & Undecided & Arizona (R) & Undecided & Undecided \\
\hline Louisiana (R) & Oppose & Oppose & Colorado (D) & Undecided & Support \\
\hline Maine (R) & Oppose & Oppose & Idaho (R) & Undecided & Undecided \\
\hline Mississippi (R) & Oppose & Oppose & Indiana $(\mathrm{R}) \mathbb{\int}$ & Undecided & Oppose \\
\hline Nebraska (R) & Oppose & Oppose & Kansas (R) & Undecided & Undecided \\
\hline South Carolina (R) & Oppose & Oppose & Kentucky (D) & Undecided & Undecided \\
\hline Texas (R) & Oppose & Oppose & Michigan (R) & Undecided & Undecided \\
\hline Virginia (R) & Oppose & Oppose & Missouri (D) & Undecided & Support \\
\hline Arkansas (D) & Support & Support & Montana (D)』 & Undecided & Support \\
\hline California (D) & Support & Support & Nevada (R) & Undecided & Support \\
\hline Connecticut (D) & Support & Support & New Hampshire (D)』 & Undecided & Support \\
\hline Delaware (D) & Support & Support & New Jersey (R) & Undecided & Undecided \\
\hline District of Columbia (D) & Support & Support & New Mexico (R) & Undecided & Support \\
\hline Hawaii (D) & Support & Support & North Carolina (R)』 & Undecided & Undecided \\
\hline Illinois (D) & Support & Support & North Dakota (R) & Undecided & Undecided \\
\hline Maryland (D) & Support & Support & Ohio (R) & Undecided & Undecided \\
\hline Massachusetts (D) & Support & Support & Oklahoma (R) & Undecided & Oppose \\
\hline Minnesota (D) & Support & Support & Pennsylvania (R) & Undecided & Undecided \\
\hline New York (D) & Support & Support & South Dakota (R) & Undecided & Oppose \\
\hline Oregon (D) & Support & Support & Tennessee (R) & Undecided & Undecided \\
\hline Rhode Island (I) & Support & Support & Utah (R) & Undecided & Undecided \\
\hline Vermont (D) & Support & Support & West Virginia (D) & Undecided & Undecided \\
\hline \multirow[t]{2}{*}{ Washington (D)』 } & Support & Support & Wisconsin (R) & Undecided & Undecided \\
\hline & & & Wyoming (R) & Undecided & Oppose \\
\hline
\end{tabular}

* ACA denotes Affordable Care Act, D Democrat, I Independent, and R Republican.

$\uparrow$ "After election" refers to views as of January 13, 2013. In states with newly elected governors, "before election" refers to the views of the outgoing governor, and "after election" refers to the views of the governor-elect.

$¥$ The mayor is the head of the government of the District of Columbia. In our analysis, we therefore treated the mayor of the

District of Columbia as the figure comparable to the governors in the 50 states.

$\int$ In these states, a new governor was elected in November 2012.

in the executive branch and often set the terms of debate with the legislature. We collected public statements (for full methods and references, see the Supplementary Appendix, available with the full text of this article at
NEJM.org) ${ }^{1,2}$ from documents published in the summer and fall of 2012. In five states with newly elected governors, we included campaign statements from the winning candidate. We identified major themes voiced by governors and cross-tabulated them according to whether each governor supports the expansion, opposes it, or remains undecided (see Table 1). We then identified any changes since the election. 
Table 2. Common Themes in Governors' Statements on Expanding Medicaid, Stratified by Support for or Opposition to the Expansion."

Group and Theme

13 Governors opposing Medicaid expansion

Concerns about impact on state budget

States need more flexibility, freedom from federal oversight

Federal government will renege on funding

States would have to raise taxes to pay for it

Uncertainty, need more information

Medicaid is a "broken program," harms its beneficiaries

Entitlement programs create dependency

18 Governors supporting Medicaid expansion

Medicaid will help cover the uninsured

Expansion bolsters state's preexisting efforts in health care

Will save state or taxpayers money

Medicaid will improve people's health

20 Undecided governors

Uncertainty, need more information

Concerns about impact on state budget

States need more flexibility, freedom from federal oversight

Worried about having to cut funding for education and other programs

Waiting until after election to make decision

* Data are based on an analysis of 253 articles published between June 28 and December 7, 2012. Support for or opposition to the Medicaid expansion was determined on the basis of the most recent comments made by governors, their administrations, or both. Since the time of this analysis, 3 additional governors announced their support for the expansion in early January, bringing the revised total to 21 governors in support and 17 undecided. See the Supplementary Appendix for details on methods and a full reference list.

Table 2 shows the most common themes, according to governors' support for or opposition to the Medicaid expansion. Among governors opposed to expanding Medicaid, statements about affordability and impact on state budgets were nearly universal (92\%). Cost concerns fell into several categories. Some pointed to the so-called woodwork effect, in which the ACA could draw previously eligible but unenrolled persons into Medicaid, at greater cost to the state. More than half the governors opposing expansion predicted that the federal government would renege on the generous terms of the ACA and scale back its share of Medicaid spending. Newly elected Governor Mike Pence (R-IN) compared the expansion to "the classic gift of a baby elephant. . . . The federal government says, 'We'll pay for all the hay - for the first few years."

Beyond cost, governors expressed concern about the lack of state flexibility or their belief that Medicaid may foster dependence among beneficiaries. For instance, Dennis Daugaard (R-SD) declared that "able-bodied adults should be self-reliant" - in contrast to children or people with disabilities, the traditional Medicaid beneficiaries. Others argued that Medicaid itself is the problem, calling it a "broken program" that provides poor care. Most vividly, Rick Perry (R-TX) said that adding uninsured Texans to Medicaid is "not unlike adding a thousand people to the Titanic."

Governors supporting the expansion focused on the desire to expand coverage to uninsured persons, arguing that insurance would lead to greater access to care and improved health. Jay Nixon (D-MO) explained, "This will improve the health and the quality of life for hundreds of thousands of Missourians." Many governors who support the Medicaid expansion argued that it builds on previous coverage expansions in their states and that it would actually save their states money by replacing local dollars with federal funds. Peter Shumlin (D-VT) explained that opponents "are acting like we are not already paying for this. What we're proposing . . . is to pay less for something that we are already paying for right now."

Among uncommitted governors, there were three dominant themes. First, three quarters of these governors said they needed more information on federal requirements, cost and enrollment projections, and policy alternatives. Second, affordability was a key concern, including the possibility of decreased federal funding in the future; as Jan 
Brewer (R-AZ) explained, "At any whim they could just pull the money. So yeah, I'm a little gunshy." Finally, early on, nearly one third of undecided governors said they were waiting until the election to evaluate their options.

Although some may have expected the uncertainty to resolve swiftly after the election, that has not happened: as of January 2013, a total of 15 of the 26 governors who were undecided before the election remained undecided (see Table 1). Some of this uncertainty reflects ongoing efforts to gather information about what will be permissible under the law. Several governors petitioned Medicaid to permit partial expansions, such as including only people with incomes of up to $100 \%$ of the federal poverty level. They reasoned that the federal government would pay the full cost of tax credits for people with incomes between 100 and $138 \%$ of the poverty level who sought health insurance through an exchange, whereas under the Medicaid expansion, states will have to pay $10 \%$ of the costs in the long run. However, the Department of Health and Human Services recently clarified that partial expansions would not be permitted. ${ }^{3}$

Some ACA supporters contended that governors' opposition after the Supreme Court ruling was simply preelection political posturing and that most states would find the ACA's generous federal funding impossible to refuse. ${ }^{4}$ Some of the movement since the election bolsters this perspective: six governors have newly announced their support, including the first two Republican governors to publicly en- dorse the expansion. Two other governors who previously opposed the expansion have now indicated that their minds are not completely made up. Rick Scott (R-FL), previously one of the most vocal opponents of the law, explained, "The election is over, and President Obama won. I'm responsible for the families of Florida. . . . If I can get to yes, I want to get to yes."

However, not everyone changing position has endorsed expanding Medicaid. Five previously undecided Republican governors are now opposed, and some governors say they won't decide until 2015 or 2016. Some opposition may remain a negotiating ploy by governors with respect to opposing lawmakers or the federal government, but predictions of a rapid, pro-expansion resolution were apparently mistaken. Moreover, governors are only part of the story; several statehouses (including the Republican-led Missouri legislature and the newly Democratic Maine legislature) plan to oppose their governors' positions on the expansion.

Overall, these results demonstrate governors' conflicting views about the value of expanding insurance coverage versus the costs and federal oversight involved in doing so through Medicaid. As the dust has settled after the elections, no clear consensus has emerged, with 17 states still undecided and well under half supporting Medicaid expansion. It now appears that the ACA's 2014 coverage expansion will have large unintended gaps, as low-income adults in at least a dozen states remain ineligible for any kind of public subsidy for health insurance. Although those with incomes above $100 \%$ of the federal poverty level will be eligible for tax credits for exchange coverage in states that decline to expand Medicaid, that will still leave millions of adults living below the poverty level without health insurance and without the means of acquiring it.

Though Medicaid was initially enacted in 1965, nine states did not participate until 1970 or later, and it took nearly 20 years before the last holdout joined. ${ }^{5}$ One can only speculate about whether that history is about to be repeated, with insurance coverage for millions and the fate of the ACA hanging in the balance.

Disclosure forms provided by the authors are available with the full text of this article at NEJM.org.

From the Department of Health Policy and Management, Harvard School of Public Health, Boston.

This article was published on January 16, 2013, at NEJM.org.

1. Where each state stands on ACA's Medicaid expansion. Washington, DC: Advisory Board Company, 2012 (http://www.advisory .com/Daily-Briefing/2012/11/09/

MedicaidMap).

2. Across the USA. McLean, VA: USA Today, 2012 (http://usatoday30.usatoday.com/news/ usaedition/2012-07-13-states13box _

st_u.htm).

3. Frequently asked questions on exchanges, market reforms, and Medicaid. Baltimore: Centers for Medicare \& Medicaid Services, December 10, 2012 (http://cciio.cms.gov/ resources/files/exchanges-faqs-12-10-2012 .pdf).

4. Medicaid expansion may turn out to be an offer states can't refuse. Mother Jones. July 18, 2012 (http://www.motherjones.com/ kevin-drum/2012/07/medicaid-expansionmay-turn-out-be-offer-states-cant-refuse).

5. A historical review of how states have responded to the availability of federal funds for health coverage. Washington, DC: Kaiser Commission on Medicaid and the Uninsured, August 2012 (http://www.kff.org/medicaid/ upload/8349.pdf).

DOI: 10.1056/NEJMp1215785

Copyright (C) 2013 Massachusetts Medical Society. 